ISSN : $2302-1590$

E-ISSN: $2460-190 \mathrm{X}$

ECONOMICA

Journal of Economic and Economic Education Vol.2 No.1 (67- 76)

\title{
PERBEDAAN HASIL BELAJAR IPS TERPADU MENGGUNAKAN STRATEGI PEMBELAJARAN AKTIF TIPE STUDENT RECAP DENGAN PEMBELAJARAN KONVENSIONAL PADA KELAS VIII MTS TI BATANG KABUNG
}

\author{
Desri Wahyuni \\ Mahasiswa Program Studi Pendidikan Ekonomi STKIP- PGRI Sumbar \\ Jl. Gunung Pangilun No.1, Padang Sumatera Barat \\ Email: desriwahyuni@yahoo.com \\ Ansofino \\ Dosen Program Studi Pendidikan Ekonomi STKIP- PGRI Sumbar \\ Jl. Gunung Pangilun No.1, Padang Sumatera Barat \\ Email: ansofino2001@yahoo.com
}

Submited: 2013.08.19 Reviewed:2013.09.11 Accepted: 2013.10.13

http://dx.doi.org/10.22202/economica.2013.v2.i1.219

\begin{abstract}
Core problem in this research is there are difference of learning outcome of IPS terpadu by using active study strategy type student recap with conventional study. This research use experiment method at class VIII MTS TI Batang Kabung, by using two class as sampel, VIIIE as experiment class and class VIIID as control class. Technique used to test hypothesis is test equality of mean with t test. Result of research indicate that Firstly: There are difference learning outcome between active study of type student recap with study of konvesional IPS Terpadu learning outcome class student of VIII MTS Teluk Kbaung posed with hypothesis test ttest $=2,973$ while ttable $=1,67, \mathrm{HO}$ refused and $\mathrm{H1}$ accepted. And obtained by average value of experiment class equal to 70.34 and class control equal to 60 where specified KKM equal to 70. Both: active Strategy Study of type of student recap can improve learning outcome class student of VIII MTS TI Teluk Kbaung, this matter can be seen from step activity of the study, especially at activity of exploration, confirmation and elaboration at experiment class and control class, have manifestly proven statistically can improve score result of final tes at experiment class.
\end{abstract}

\footnotetext{
Abstrak

Pokok persoalan yang dikemukakan dalam penelitian ini adalah apakah terdapat perbedaan hasil belajar IPS Terpadu siswa dengan menggunakan strategi pembelajaran aktif tipe student recap dengan pembelajaran konvensional. Penelitian ini menggunakan metode eksperimen yang dilakukan pada siswa kelas VIII MTs TI Batang Kabung, dengan menggunakan dua kelas sebagai sampel, yaitu kelas VIII $I_{E}$ sebagai kelas eksperimen

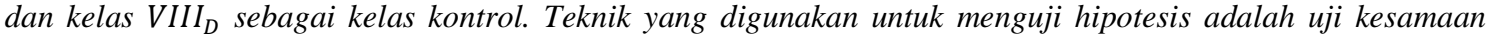
rata-rata melalui uji t.Hasil penelitian menunjukkan bahwa Pertama: Terdapat perbedaan secara nyata hasil belajar antara pembelajaran aktif tipe student recap dengan pembelajaran konvesional terhadap hasil belajar IPS Terpadu siswa kelas VIII MTs TI Batang Kabung yang ditunjukkan oleh nilai uji hipotesis (uji-t) $t_{\text {hitung }}=$ 2,973 sedangkan $t_{\text {tabel }}=1,67$ artinya $t_{\text {hitung }}>t_{\text {tabel }}$, dengan demikian $H_{0}$ ditolak dan $H_{1}$ diterima. Dan nilai rata-rata yang diperoleh kelas eksperimen sebesar 70.34 dan kelas kontrol sebesar 60 dimana KKM yang ditetapkan sebesar 70. Kedua: Strategi pembelajaran aktif tipe student recap dapat meningkatkan hasil belajar siswa kelas VIII MTS TI Batang Kabung, hal ini dapat dilihat dari langkah kegiatan pembelajaran yang dilakukan, terutama pada kegiatan eksplorasi, elaborasi dan konfirmasi pada kelas eksperimen dan kelas kontrol, telah secara nyata terbukti secara statistik mampu meningkatkan skor hasil tes akhir pada kelas eksperimen pada penelitian ini.

Keywords: learning outcomes, student recap, IPS Terpadu
} 


\section{PENDAHULUAN}

Seiring dengan perkembangan ilmu pengetahuan dan teknologi yang terus berkembang pesat sekarang ini, akan membawa berbagai dampak kemajuan diberbagai bidang kehidupan. Untuk dapat mengikuti dan meningkatkan ilmu pengetahuan dan teknologi tersebut, diperlukan sumber daya manusia yang berkualitas melalui pendidikan, karena pendidikan sangat berperan dalam membentuk pribadi manusia.

Pendidikan merupakan pengalaman belajar yang berlangsung dalam segala lingkungan dan sepanjang hidup. Pendidikan juga situasi hidup yang mempengaruhi individu (Mudyahardjo, 2002:3).

Tujuan Pendidikan Nasional menurut UU No. 20 Tahun 2003 tentang sistem pendidikan nasional yang menyatakan bahwa:

Pendidikan nasional berfungsi mengembangkan kemampuan dan membentuk watak serta peradaban bangsa yang bermanfaat dalam rangka mencerdaskan kehidupan bangsa, bertujuan untuk berkembangnya potensi peserta didik agar menjadi manusia beriman dan bertaqwa kepada Tuhan Yang Maha Esa, berakhlak mulia, sehat berilmu, cakap, kreatif, mandiri dan menjadi warga negara yang demokratis serta tanggung jawab.

Mengingat pentingnya peran pendidikan tersebut, sudah sepantasnya aspek ini menjadi perhatian pemerintah dalam rangka peningkatan kualitas pendidikan, yaitu dengan meningkatkan sumber daya masyarakat yang berkualitas khususnya potensi sumber daya manusia peserta didik. Pemerintah terus berbenah dan berusaha untuk meningkatkan mutu pendidikan di Indonesia, seperti melakukan perubahan kurikulum, yakni dari kurikulum 1994 menjadi KurikulumBerbasis Kompetensi (KBK) dan disempurnakan lagi menjadi Kurikulum Tingkat Satuan Pendidikan atau yang lebih dikenal dengan KTSP.

Di dalam KTSP seorang guru berperan sebagai fasilitator. Guru diharapkan dapat memainkan perannya dengan baik. "Agar guru mampu memainkan perannya sebagai fasilitator dalam pembelajaran, terdapat beberapa hal yang harus dipahaminya dari peserta didik, yaitu kemampuan, potensi, minat, hobby, sikap, kepribadian, kebiasaan, catatan kesehatan, latar belakang keluarga, dan kegiatannya di sekolah" (Mulyasa, 2010:163).

Namun kenyataannya berbeda dengan apa yang terjadi di MTs TI Batang Kabung berdasarkan observasi pada tanggal 28 Januari 2013 yang dilakukan di MTs TI Batang Kabung pelaksanaan KTSP belum sepenuhnya diterapkan, dimana dalam proses belajar mengajar masih bersifat teacher centered, sedangkan dalam KTSP diharapkan siswa yang lebih aktif, dimana guru hanya sebagai fasilitator bagi siswa (student centered).

Dalam proses pembelajaran guru masih dominan menyampaikan materi seperti biasa, yaitu dengan pembelajaran secara konvensional, sehingga tidak tercipta proses pembelajaran yang menyenangkan dan bervariasi yang dapat menambah semangat belajar siswa. Akibatnya, kegiatan belajar mengajar kurang menarik dan membosankan karena siswa tidak diransang atau ditantang untuk terlibat aktif dalam proses pembelajaran. Dalam pembelajaran, siswa banyak yang tidak memperhatikan guru ketika guru sedang menjelaskan pelajaran, mereka lebih senang berbicara dengan teman sebangkunya atau mengerjakan pekerjaan lain diluar pembelajaran.

Selain itu, dalam proses pembelajaran kebanyakan siswa hanya menunggu penjelasan dari guru dan belum 
diarahkan untuk belajar secara mandiri, sehingga siswa kurang dapat mengembangkan pemikirannya. Banyak siswa yang tidak mengerti tentang materi yang diajarkan oleh guru, siswa sulit untuk memahami materi yang telah diajarkan dengan alasan materinya banyak, hal ini menyebabkan siswa yang sebenarnya masih kurang paham mengenai materi pelajaran mendapatkan hasil yang kurang memuaskan, sehingga siswa tidak memperoleh ketuntasan dalam belajar. Hal ini bisa terlihat pada Tabel 1.1 di bawah ini.

\section{Tabel 1. Nilai Rata-rata dan Persentase Ketuntasan Ujian Akhir Semester I MTs TI} Batang Kabung Tahun Pelajaran 2011/2012

\begin{tabular}{|c|c|c|c|c|c|c|c|}
\hline \multirow{2}{*}{ No } & \multirow{2}{*}{ Kelas } & \multirow{2}{*}{$\begin{array}{l}\text { Jumlah } \\
\text { Siswa }\end{array}$} & \multirow{2}{*}{$\begin{array}{l}\text { Nilai Rata- } \\
\text { rata Ujian } \\
\text { Semester I }\end{array}$} & \multicolumn{2}{|c|}{ Tuntas } & \multicolumn{2}{|c|}{ Tidak Tuntas } \\
\hline & & & & Jumlah & $\%$ & Jumlah & $\%$ \\
\hline 1. & $\mathrm{VIII}_{\mathrm{A}}$ & 26 & 71,00 & 13 & 50,00 & 13 & 50,00 \\
\hline 2. & $\mathrm{VIII}_{\mathrm{B}}$ & 29 & 63,17 & 11 & 37,93 & 18 & 62,07 \\
\hline 3. & $\mathrm{VIII}_{\mathrm{C}}$ & 29 & 61,76 & 7 & 24,14 & 22 & 75,86 \\
\hline 4. & $\mathrm{VIII}_{\mathrm{D}}$ & 28 & 59,75 & 4 & 14,29 & 24 & 85,71 \\
\hline 5. & $\mathrm{VIII}_{\mathrm{E}}$ & 30 & 58,93 & 1 & 3,30 & 29 & 96,70 \\
\hline \multicolumn{2}{|c|}{ Jumlah } & 142 & 62,92 & 36 & 25,93 & 106 & 74,07 \\
\hline
\end{tabular}

(Sumber : Guru IPS kelas VII MTs TI Batang Kabung, 2013)

Dari Tabel 1 dapat dilihat bahwa nilai ujian IPS siswa masih tergolong rendah dan masih ada siswa yang belum mencapai Kriteria Ketuntasan Minimal (KKM) yang telah ditetapkan sekolah, yaitu 70,00. Dari lima kelas VIII yang ada, terdapat empat kelas yang belum mencapai KKM (Kriteria Ketuntasan Minimum) yang ditetapkan oleh sekolah. Kelas $\mathrm{VIII}_{\mathrm{B}}, \mathrm{VIII}_{\mathrm{C}}, \mathrm{VIII}_{\mathrm{D}}, \mathrm{VIII}_{\mathrm{E}}$, belum mencapai standar

Kriteria Ketuntasan Minimum (KKM). Sementara satu kelas lainnya sudah mencapai Kriteria Ketuntasan Minimum (KKM), yaitu kelas VIII $_{\mathrm{A}}$.

Berdasarkan hasil observasi terhadap beberapa siswa kelas VIII tersebut, diungkapkan pada kenyataannya mereka lebih senang mendengar saja apa yang disampaikan oleh guru, sehingga pembelajaran dikelas didominasi oleh guru. Siswa lebih senang bertanya kepada temannya dibandingkan bertanya kepada guru, tanpa mempertimbangkan jawaban dari temannya tersebut benar dan salah. Saat temannya tidak dapat memberikan jawaban dengan rinci, mereka lebih memilih mencotek jawaban temannya tersebut. Selain itu didapatkan informasi bahwa mereka susah memahami soal-soal yang diberikan oleh guru, sehingga mereka beranggapan IPS Terpadu itu merupakan pelajaran yang membosankan.

Dalam proses belajar mengajar siswa tidak mengaktifkan dirinya selama kegiatan pembelajaran, siswa hanya menunggu instruksi dari guru. Hal ini disebabkan siswa tidak memiliki semangat belajar mandiri, selalu bergantung pada guru, tanpa diterangkan guru siswa tidak mau belajar sendiri, selain itu kurangnya sumber belajar mengakibatkan siswa tidak memiliki kesempatan untuk mengetahui lebih dahulu materi yang akan dibahas.

Melihat semua permasalahan diatas berarti proses pembelajaran IPS Terpadu belum berjalan secara optimal, oleh karena itu guru dituntut untuk memberikan bimbingan dan menciptakan situasi yang kondusif sehingga apa yang disampaikan oleh guru dapat diterima dengan baik oleh siswa. Untuk menciptakan situasi yang demikian, maka perlulah guru untuk menerapkan model pembelajaran yang efektif, pendekatan dan strategi pembelajaran yang tepat, sehingga dapat memperoleh hasil belajar siswa secara optimal. Untuk mencapai hasil belajar yang optimal diperlukan suatu strategi yang dapat melibatkan siswa secara aktif selama proses pembelajaran.

Bertolak dari uraian di atas, salah satu strategi pembelajaran yang dapat mengaktifkan siswa adalah strategi 
pembelajaran aktif (active learning). Strategi pembelajaran aktif merupakan strategi yang mengajak siswa untuk belajar secara aktif. Dengan strategi ini siswa dapat menggunakan kemampuan otak mereka tanpa harus dipaksa. Siswa terlibat secara aktif saat guru menyampaikan materi pembelajaran. Dengan pembelajaran aktif ini,siswa diajak untuk turut serta dalam semua proses pembelajaran, tidak hanya mental tetapi juga fisik. Strategi pembelajaran aktif dimaksudkan untuk mengoptimalkan penggunaan semua potensi yang dimiliki oleh siswa, sehingga semua siswa dapat mencapai hasil belajar yang memuaskan sesuai dengan karakter pribadi yang mereka miliki. Disamping itu pembelajaran aktif juga dimaksudkan untuk menjaga perhatian siswa agar tetap tertuju pada proses pembelajaran.

Untuk memecahkan permasalahan tersebut, maka perlu dilakukan inovasi strategi pembelajaran aktif yang relevan. Strategi pembelajaran aktif terdiri dari beberapa tipe salah satunya adalah tipe student recap. Strategi pembelajaran aktif tipe student recap ini dapat digunakan untuk melibatkan siswa secara aktif dalam pembelajaran, mulai dari awal sampai akhir pembelajaran. Dalam strategi ini, siswa diminta untuk meringkas materi pelajaran dengan bahasa mereka sendiri kemudian melalui ringkasan tersebut siswa bisa menjelaskan kepada teman-temannya. Dengan demikian siswa tidak mudah lupa terhadap materi yang telah dipelajari.

Bertitik tolak dari uraian di atas maka peneliti tertarik untuk melakukan penelitian tentang "Perbedaan Hasil Belajar IPS Terpadu Menggunakan Strategi Pembelajaran Aktif Tipe Student Recap dengan Pembelajaran Konvensional Pada Kelas VIII MTs TI Batang Kabung"

\section{Hakekat Pembelajaran berdasarkan KTSP}

Kurikulum perlu dikembangkan sesuai dengan kemajuan zaman dan kebutuhan siswa, KTSP merupakan acuan dari pelaksanaan pendidikan untuk mengembangkan berbagai ranah pendidikan sejalan dengan otonomi daerah. Kurikulum sangat bagus disesuaikan dengan kebutuhan daerah masing-masing, karena kebutuhan pendidikan di setiap daerah berbeda-beda sesuai dengan karakteristik daerahnya.

Keadaan yang dialami oleh suatu daerah tidak seutuhnya diketahui oleh pusat seperti bagaimana pendidikan yang selayaknya diberikan, oleh sebab itu perlu adanya kerjasama antara pemerintah daerah dengan pemerintah pusat, yakni salah satunya dalam penerapan kurikulum. Ada beberapa hal yang penting diketahui seputar KTSP, di antaranya :

a. Pengertian KTSP

Dalam Standar Nasional Pendidikan (SNP pasal 1, ayat 15), dijelaskan bahwa KTSP adalah kurikulum operasional yang disusun dan dilaksanakan oleh masing-masing satuan pendidikan.

b. KTSsP disusun dan dikembangkan berdasarkan UU no. 20 Tahun 2003 tentang Sistem Pendidikan Nasional pasal 36 ayat 1 dan 2 sebagai berikut :

1) Pengembangan kurikulum mengacu pada Standar Nasional Pendidikan untuk mewujudkan Tujuan Pendidikan Nasional

2) Kurikulum pada semua jenjang dan jenis pendidikan dikembangkan dengan prinsip diversifikasi sesuai dengan satuan pendidikan, potensi daerah, dan peserta didik (Mulyasa 2010:20).

c. Tujuan KTSP

1) Secara umum tujuan diterapkannya KTSP adalah untuk memandirikan dan memberdayakan satuan pendidikan melalui pemberian kewenangan (otonomi) kepada lembaga pendidikan. Dengan adanya kewenangan dari sekolah dalam penyusunan kurikulum, memungkinkan sekolah menyesuaikan dengan tuntutan 
kebutuhan siswa, keadaan sekolah dan kondisi sekolah.

2) Secara khusus tujuan diterapkannya KTSP adalah :

a) Meningkatkan mutu pendidikan melalui kemandirian dan inisiatif sekolah dalam mengembangkan

kurikulum, mengelola dan memberdayakan sumber daya yang tersedia.

b) Meningkatkan kepedulian warga sekolah dan masyarakat dalam pengembangan kurikulum melalui pengambilan keputusan bersama.

c) Meningkatkan kompetensi yang sehat antar satuan pendidikan tentang kualitas pendidikan yang akan dicapai.

d. Strategi pengembangan KTSP

1) Sosialisasi KTSP di sekolah

2) Menciptakan suasana yang kondusif

3) Menyiapkan sumber belajar

4) Membina disiplin

5) Mengembangkan kemandirian kepala sekolah

6) Mengembangkan karakter guru

7) Memberdayakan staf (Mulyasa, 2010:153-165).

e. Kelebihan-kelebihan KTSP

1) Mendorong terwujudnya otonomi sekolah dalam menyelenggarakan pendidikan.

2) Mendorong para guru, para kepala sekolah dan pihak manajemen sekolah untuk meningkatkan kreativitasnya dalam menjalankan programprogram pendidikan.

3) KTSP sangat memungkinkan bagi setiap sekolah untuk menitik beratkan dan mengembangkan mata pelajaan tertentu yang akseptabel bagi kebutuhan siswa.
4) KTSP memberikan peluang yang lebih luas kepada sekolahsekolah plus untuk mengembangkan kurikulum yang sesuai dengan kebutuhan.

5) KTSP mengurangi beban belajar siswa yang sangat padat dan memberatkan $\pm 20 \%$.

\section{Hakekat Belajar Dan \\ Pembelajaran}

Belajar merupakan tindakan dan prilaku siswa yang kompleks. Sebagai tindakan, maka belajar hanya dialami oleh siswa sendiri. Siswa adalah penentu terjadinya atau tidak terjadinya proses belajar. Proses belajar terjadi berkat siswa memperoleh sesuatu yang ada dilingkungan sekitar. (Dimyati, 2006:7).

Pembelajaran merupakan inti dari kegiatan pendidikan di sekolah. Kegiatan ini melibatkan guru dan siswa, dengan titik berat pembelajaran adalah membelajarkan siswa. Bicara mengenai pembelajaran, tidak terlepas dari kata belajar.

Pengertian belajar menurutSudjana (2008:28) menyatakan bahwa "belajar adalah suatu proses yang ditandai dengan adanya perubahan pada diri seseorang". Perubahan sebagai proses belajar dapat ditunjukkan dalam berbagai bentuk seperti berubah pengetahuan, pemahaman, sikap dan tingkah laku, keterampilan, kecakapan dan kemampuan, daya reaksinya, daya penerimaan dan aspek-aspek lain yang ada pada individu.

Berdasarkan teori di atas dapat disimpulkan bahwa belajar hakekatnya merupakan suatu perubahan tingkah laku yang terjadi pada diri seseorang setelah berakhirnya proses belajar. Dalam belajar selalu diiringi dengan perubahan, tergantung bagaimana seseorang merefleksikan proses belajar yang ia dapatkan.

Pembelajaran pada hakekatnya merupakan suatu proses interaksi yang dilakukan oleh dua orang pelaku, yaitu guru (pelaku mengajar) dan siswa (pelaku belajar), baik interaksi secara langsung seperti kegiatan tatap muka maupun secara tidak langsung, yaitu dengan 
menggunakan berbagai media pembelajaran.

Berdasarkan uraian di atas dimaknai bahwa dalam pembelajaran semua unsur ikut terlibat, keaktifan dituntut tidak hanya dari kreativitas guru saja, tetapi juga dari tindakan siswa itu sendiri. Salah satu cara mmemfasilitasi belajar siswa adalah dengan cara menciptakan suasana yang kondusif dan interaksi siswa dalam belajar.

\section{Strategi Pembelajaran Aktif}

Strategi pembelajaran aktif dimaksudkan untuk mengoptimalkan penggunaan semua potensi yang dimiliki oleh anak didik sehingga semua anak dapat mencapai hasil belajar yang memuaskan sesuai dengan karakteristik pribadi yang mereka miliki. Disamping itu pembelajaran aktif juga dimaksudkan untuk menjaga perhatian siswa agar tertuju pada proses pembelajaran.

Lebih dari 2400 tahun yang lalu, Confisius mendeklarasikan tiga pernyataan sederhana yang mengungkapkan pentingya belajar aktif yang dikemukakan Silberman (2009:1) yaitu :

What I hear, I forget (apa yang saya dengar, saya lupa)

What I see, I remember (apa yang saya lihat, saya ingat)

What I do, I understand (apa yang saya lakukan, saya paham)

Pernyataan ini dimodifikasi oleh Silberman dan diperluas menjadi paham belajar aktif :

What I hear, Iforget

What I hear, see, and ask question about or discuss with someone else, I begin to understand

What I hear, see, discuss, and do, I acquire knowledge and skill

What I teach to another, I master

(Apa yang saya dengar, saya lupa)

(Apa yang saya dengar, lihat, dan tanyakan atau diskusikan dengan beberapa kolega/teman, saya mulai paham)

(Apa yang saya dengar, lihat, diskusikan, dan lakukan, saya memperoleh pengetahuan dan keterampilan)

(Apa yang saya ajarkan pada orang lain, saya menguasainya).

Ada beberapa alasan Silberman membuat pernyataan diatas diantaranya adalah sebagian besar orang cenderung lupa tentang apa yang mereka dengar. Alasan yang menarik adalah ada kaitannya dengan tingkat kecepatan bicara guru dan tingkat kecepatan mendengar siswa. Dan ketika mengajar, guru harus mempunyai pendengaran dan penglihatan yang baik, karena penyampaian materi pelajaran akan dapat diperkuat oleh kedua hal tersebut. Mendengar dan melihat saja tidaklah cukup untuk belajar.

Belajar aktif merupakan belajar yang memperbanyak keaktifan siswa dalam belajar. Dimana siswa diharapkan dapat mencari informasi, mengkaji gagasan, memecahkan masalah dan menerapkan apa yang telah mereka pahami. Siswa dikatakan aktif, jika selama proses belajar siswa dapat melakukan sesuatu dengan aktif.

Dari kegiatan yang dilakukan guru dan siswa, maka dalam belajar aktif guru sebagai fasilitator dan motivator. Guru memberikan bantuan dan dorongan kepada siswa, sedangkan yang harus aktif dalam proses belajar berlangsung adalah siswa sendiri. Walaupun dalam pembelajaran aktif dituntut siswa yang aktif, tetapi sebenarnya terciptanya pembelajaran yang aktif tersebut dibangun oleh guru itu sendiri. Rusman (2012:324) mengungkapkan bahwa pembelajaran aktif merupakan pendekatan pembelajaran yang lebih banyak melibatkan aktivitas siswa dalam mengakses berbagai informasi dan pengetahuan untuk dibahas dan dikaji dalam proses pembelajaran dikelas, sehingga mereka mendapatkan berbagai pengalaman yang dapat meningkatkan pemahaman dan kompetensinya.

Dalam pembelajaran aktif, guru lebih banyak memosisikan dirinya sebagai fasilitator, yang bertugas memberikan kemudahan belajar kepada siswa. Siswa 
terlibat secara aktif dan berperan dalam proses pembelajaran, sedangkan guru lebih banyak memberikan arahan dan bimbingan, serta mengatur sirkulasi dan jalannya proses pembelajaran. Holt dalam Silberman (2009:5) yang menyatakan bahwa proses belajar akan meningkat jika siswa diminta untuk melakukan hal berikut

a. Mengungkapkan informasi dengan bahasa mereka sendiri

b. Memberi contoh-contoh

c. Mengenalnya dalam berbagai samaran dan kondisi

d. Melihat hubungan antara satu fakta atau gagasan dengan yang lain

e. Meggunakannya dengan berbagai cara

f. Memperkirakannya berapa konsekuensinya

g. Mengungkapkan lawan atau kebalikannya

Proses belajar sesungguhnya bukanlah kegiatan menghafal, karena banyak hal yang diingat siswa akan hilang dalam beberapa jam. Untuk mengingat apa yang telah diajarkan, siswa harus mengulang atau memahaminya kembali dengan baik.

\section{Strategi Pembelajaran Aktif Tipe Student Recap}

Dalam dunia pendidikan Silberman (2009:65-299) menceritakan 101 cara belajar aktif diantaranya : memilah dan memilih kartu, pertanyaan rekayasa, student recap dan lain-lain. Diantara cara yang dikemukakan penulis memilih tipe student recap. Karena tipe student recap ini yang penulis anggap cocok untuk diterapkan dalam pembelajaran IPS Terpadu.

Tipe student recapadalah salah satu teknik intruksional dari belajar aktif yang termasuk dalam reviewing strategis (strategi pengulangan). Tipe ini berhubungan dengan cara-cara untuk mengingat kembali apa yang telah mereka pelajari dan menguji kemampuan serta pengetahuan yang telah mereka peroleh.
Hal ini sesuai dengan yang telah dikemukakan oleh Silberman (2009:239) :

Salah satu cara yang paling meyakinkan untuk menjadikan belajar tepat adalah menyertakan waktu untuk meninjau apa yang telah dipelajari. Materi yang telah ditinjau (review) oleh peserta didik mungkin disimpan lima kali lebih kuat dari materi yang tidak ditinjau. Hal ini karena peninjauan memudahkan peserta didik untuk mempertimbangkan informasi dan menemukan caracara untuk menyimpannya dalam otaknya.

Strategi ini memberikan kesempatan bagi siswa untuk meringkas apa yang mereka pelajari dan menyampaikan ringkasan yang telah dibuatnya kepada teman-temannya, dengan demikian diharapkan siswa-siswa lebih memahami apa yang dijelaskan oleh guru dan juga penjelasan dari ringkasan yang dibuat oleh temannya sendiri.

Silberman

mengemukakan prosedur pembelajaran dengan menggunakan tipe student recap ini adalah :

a. Jelaskan kepada peserta didik bahwa bagi anda, menyediakan ringkasan pelajaran adalah bertentangan dengan prinsip belajar aktif.

b. Kelompokkan peserta didik ke dalam kelompok-kelompok yang terdiri dari empat sampai lima anggota.

c. Perintahkan agar setiap kelompok membuat ringkasan sendiri tentang sesi pelajaran. Doronglah mereka untuk membuat out-line, peta pikiran, atau buatan-buatan yang lain yang akan memudahkan mereka untuk mengomunikasikan ringkasan kepada yang lain.

d. Gunakan di antara pernyataanpernyataan berikut ini untuk membimbing kerja mereka :

1) Topik-topik utama yang telah kita uji? 
2) Poin-poin kunci apa yang telah muncul dalam pelajaran hari ini?

3) Pengalaman apa yang telah anda peroleh hari ini? Apa yang telah kamu ambil darinya?

4) Ide-ide apa atau saran-saran apa yang kamu ambil dalam pelajaran itu?

e. Ajaklah kelompok untuk berbagi ringkasan mereka. Berikan tepuk tangan atas usaha mereka.

Berdasarkan langkah-langkah dari pembelajaran aktif tipe student recap yang dikemukakan oleh Silberman tersebut maka penulis dapat memodifikasinya sebagai berikut:

a. Siswa dikelompokkan dalam beberapa kelompok yang terdiri dari empat sampai lima orang siswa.

b. Siswa diperintahkan untuk membuat ringkasan sesuai dengan kreasi masing-masing kelompok, baik itu menggunakan peta konsep, peta pikiran atau sesuatu yang lain yang menurut mereka menarik dan mereka bisa paham terhadap materi.

c. Siswa disuruh untuk mempresentasikan atau menyampaikan ringkasan yang dibuat oleh siswa tersebut kepada temantemannya.

d. Setelah presentasi atau penyampaian dari siswa tersebut berakhir, sediakan waktu untuk sesi pertanyaan. Setelah semuanya berakhir, berikan tepuk tangan atau bentuk penghargaan yang lain kepada kelompok yang membuat ringkasan paling bagus dan presentasi atau penyampaian ringkasan terbaik kepada teman-temannya.

Setiap kelompok harus siap untuk tampil karena ditunjuk secara acak oleh guru. Secara tidak langsung mereka akan berusaha untuk mengingat dengan baik materi yang telah diajarkan oleh guru hal ini akan mengakibatkan siswa akan aktif dalam belajar.

\section{Hipotesis Penelitian}

Hipotesis adalah suatu jawaban yang bersifat sementara terhadap permasalahan penelitian, sampai terbukti melalui data yang terkumpul. Rumusan hipotesis dari penelitian ini adalah :

1. Terdapat perbedaan hasil belajar siswa MTs TI Batang Kabung pada mata pelajaran IPS Terpadu yang diajarkan dengan strategi pembelajaran aktif tipe student recap dengan pembelajaran konvensional.

2. Hasil belajar siswa yang diajar dengan strategi aktif tipe student recap meningkat daripada hasil belajar siswa yang diajar dengan pembelajaran konvensional.

\section{METODE PENELITIAN Jenis Penelitian}

Berdasarkan permasalahan dan tujuan penelitian yang telah dikemukakan, maka jenis penelitian ini merupakan penelitian eksperimen semu (quasy experimental research). Dalam penelitian eksperimen ini terdapat kelompok eksperimen yang sengaja diberi perlakuan yang berbeda. Disamping itu ada kelompok kontrol yang merupakan kelompok pembanding yang tidak diberi perlakuan.

\section{Tempat dan Waktu Penelitian}

Penelitian ini dilaksanakan di MTs TI Batang Kabung. Waktu penelitian diperkirakan pada bulan Agustus 2013.

\section{Populasi dan Sampel}

Populasi dalam penelitian ini adalah seluruh siswa kelasVIIIMTs TI Batang Kabung pada tahun pelajaran 2011/2012 yang berjumlah 142 orang. Sampel dalam penelitian ini peneliti mengambil kelasVIII $\mathrm{E}_{\mathrm{E}}$ sebagai kelas eksperimen dan kelasVIII ${ }_{\mathrm{E}}$ sebagai kelas kontrol.

\section{PEMBAHASAN}

Penelitian ini dilakukan berdasarkan kepada standar kompetensi yang di ajarkan yaitu memahami kegiatan pelaku ekonomi di masyarakat, dengan kompetensi dasar adalah mendeskripsikan hubungan antara kelangkaan sumber daya dengan kebutuhan manusia yang tidak terbatas. Berdasarkan kompetensi dasar 
tersebut ada beberapa indikator yang akan dibahas yaitu kelangkaan, kebutuhan serta alat pemuas kebutuhan manusia yang diterapkan pada kedua kelas sampel, yaitu kelas eksperimen dan kelas kontrol, dimana kelas eksperimen adalah kelas $\mathrm{VIII}_{\mathrm{E}}$ dan kelas kontrol adalah kelas $\mathrm{VIII}_{\mathrm{D}}$.

Pada kelas eksperimen

pembelajaran dilakukan dengan menggunakan pembelajaran aktif tipe student recap. Sedangkan pada kelas kontrol peneliti menggunakan pembelajaran konvensional.Berdasarkan langkah-langkah yang dilakukan pada kedua kelas sampel, diperoleh hasil belajar siswa dengan melakukan tes akhir terhadap materi yang telah dipelajari, dengan jumlah soal sebanyak 20 buah. Dari hasil tes akhir tersebut didapat skor hasil tes akhir berdasarkan setiap indikator dalam kompetensi dasar. Adapun skor perolehan tersebut sebagai berikut:

Tabel 2. Skor perolehan tes akhir siswa kelas eksperimen dan kelas kontrol

\begin{tabular}{|c|c|c|c|c|c|}
\hline \multirow{2}{*}{ No } & \multirow{2}{*}{ Indikator } & \multicolumn{2}{|c|}{ Eksperimen } & \multicolumn{2}{|c|}{ Kontrol } \\
\hline & & Skor & Rata-rata & Skor & Rata-rata \\
\hline 1. & $\begin{array}{l}\text { Mendeskripsikan arti kelangkaan } \\
\text { dan faktor penyebab terjadinya } \\
\text { kelangkaan. }\end{array}$ & 34 & 17 & 21 & 10,5 \\
\hline 2. & $\begin{array}{l}\text { Mengidentifikasi usaha-usaha } \\
\text { manusia dalam mengatasi } \\
\text { kelangkaan. }\end{array}$ & 24 & 24 & 22 & 22 \\
\hline 3. & $\begin{array}{l}\text { Mendeskripsikan pengertian, } \\
\text { macam-macam dan faktor-faktor } \\
\text { yang menentukan kebutuhan. }\end{array}$ & 224 & 20,36 & 177 & 16,09 \\
\hline 4. & $\begin{array}{l}\text { Mengidentifikasi arti dan macam- } \\
\text { macam alat pemenuhan kebutuhan }\end{array}$ & 126 & 21 & 89 & 14,83 \\
\hline & Jumlah & 408 & 82,36 & 309 & 63,42 \\
\hline
\end{tabular}

Berdasarkan tabel diatas dapat dilihat bahwa terdapat perbedaan rata-rata dari perolehan skor hasil tes akhir yang dilakukan oleh kedua kelas sampel. Hal ini dapat dilihat dari hasil tes akhir siswa kelas eksperimen dengan perolehan skor sebanyak 408 dan rata-rata perolehan skor 82,36 . Sementara pada kelas kontrol memperoleh skor sebanyak 309 dan ratarata prolehan skor 63,42 .

Perbedaan skor rata-rata antara kelas eksperimen dengan kelas kontrol telah dibuktikan dengan uji statistik t, dimana nilai $t_{\text {hitung }}$ adalah sebesar 2,973, dibandingkan dengan nilai $t_{\text {tabel }}$ sebesar 1,67, sehingga perbedaan skor rata-rata hasil belajar siswa dengan menggunakan pembelajaran aktif tipe student recap dengan pembelajaran konvensional ternyata perbedaannya nyata secara statistik.Dilihat dari rata-rata perolehan skor dan uji statistik t pada kedua kelas sampel tersebut dapat disimpulkan bahwa hasil belajar siswa menjadi lebih baik dengan menggunakan strategi pembelajaran aktif tipe student recap dibandingkan dengan pembelajaran konvensional.

\section{PENUTUP}

\section{Kesimpulan}

Berdasarkan deskripsi dan analisis data hasil penelitian, dapat disimpulkan bahwa:

1. Terdapat perbedaan secara nyata hasil belajar antara pembelajaran aktif tipe student recapdengan pembelajaran konvesional terhadap hasil belajar IPS Terpadu siswa kelas VIII MTs TI Batang Kabung yang ditunjukkan oleh nilai uji hipotesis (uji-t) $t_{\text {hitung }}=$ 2,973 sedangkan $t_{\text {tabel }}=1,67$ artinya $t_{\text {hitung }}>t_{\text {tabel }}$, dengan demikian $\mathrm{H}_{0}$ ditolak dan $\mathrm{H}_{1}$ diterima. Dan nilai rata-rata yang diperoleh kelas eksperimen sebesar 70.34 dan kelas kontrol sebesar 60 dimana KKM yang ditetapkan sebesar 70 . 
2. Strategi pembelajaran aktif tipe student recap dapat meningkatkan hasil belajar siswa kelas VIII MTs TI Batang Kabung, hal ini dapat dilihat dari langkah kegiatan pembelajaran yang dilakukan, terutama pada kegiatan eksplorasi, elaborasi dan konfirmasi pada kelas eksperimen dan kelas kontrol, telah secara nyata terbukti secara statistik mampu meningkatkan skor hasil tes akhir pada

\section{Saran} kelas eksperimen pada penelitian ini.

Dari penelitian ini, penulis dapat menyarankan beberapa hal sebagai berikut:

1. Diharapkan pada guru bidang stuc IPS Terpadu di MTs TI Batan Kabung ataupun sekolah lainnya untuk dapat menerapkan strategi pembelajaran aktif tipe student recap sebagai salah satu alternatif untuk meningkatkan hasil belajar IPS Terpadu siswa.

2. Diharapkan kepada peneliti berikutnya untuk meneliti lebih lanjut penelitian ini dengan menggunakan strategi pembelajaran aktif tipe student recap untuk meningkatkan hasil belajar siswa.

\section{DAFTAR PUSTAKA}

10.22202/economica.2013.v2.i1.219

Arikunto, Suharsimi. (2006). Prosedur Penelitian Suatu Pendekatan Praktik. Jakarta: Asdi Mahasatya.

(2008). Dasar-dasar Evaluasi Pendidikan.rev. ed. Jakarta: Bumi Aksara.

(2010). Prosedur Penelitian. Rineka Cipta : Jakarta.

Dimyati. (2006).Belajar dan Pembelajaran. Rineka Cipta : Jakarta.

Djamarah, dkk. (2002). Strategi Belajar Mengajar. Jakarta: Rineka Cipta.

Lie, Anita. (2002). Cooperative Learning. Jakarta: Grasinda.

Mudyahardjo, Redja. (2002). Pengantar Pendidikan. Jakarta: PT Rajagrafindo.
Mulyasa, E. (2010). Kurikulum Tingkat Satuan Pendidikan. Bandung: PT Rosda Karya.

Nasution.S. (2000). Berbagai Pendekatan Dalam Proses Belajar Mengajar. Jakarta: PT. Bina Aksara.

Pertiwi, rini putri.(2009). Upaya Meningkatkan Aktivitas Dan Hasil Belajar Ekonomi Melalui Pemberian Tugas Meringkas Materi Dan Speed Test Diakhir Pembelajaran Siswa X 8 SMA NEGERI 2 Bukit Tinggi. Padang: Universitas Negeri Padang. (Tidak Dipublikasikan)

RI. (2003). Undang-Undang No. 20 Tahun 2003 Tentang Sistem Pendidikan Nasional. Jakarta : CV Eka Jaya.

Rusman. (2012). Model-Model Pembelajaran. Jakarta: Rajawali Pers.

Santoso, Singgih. 2010. Statistik multivariat. Jakarta: Gramedia Jakarta.

Silberman, Mel. (2009). Active Learning 101 Pembelajaran Aktif. Yogyakarta: Insan Madani.

Sudijono, Anas. 2011. Pengantar Evaluasi Pendidikan. Jakarta: PT. Rajagrafindo Persada.

Sudjana.(2002).Penilaian Hasil Belajar Mengajar. Bandung: Remaja Rosdakarya.

(2005). Metode Statistika. Bandung: Tarsito Bandung.

2008). Dasar-Dasar Proses Belajar Mengajar. Bandung: Sinar Baru Algen Sindo Offset .

Suryabrata, Sumadi. (2011). Metodologi Penelitian. Jakarta: Rajagrafindo Persada.

Suryosubroto. (2009). Proses Belajar Mengajar di Sekolah. Jakarta: Rineka Cipta.

Wahyuni, isra.(2008).Perbedaan Hasil Belajar Ekonomi Siswa Menggunakan Model Pembelajaran Aktive Learning Melalui Metode Ikhtisar Pokok Bahasan Dengan Pembelajaran Konvensional. Padang: Universitas Negeri Padang. (Tidak Dipublikasikan) 